\title{
BAP E SUBSTRATOS NA ACLIMATIZAÇÃO DE PLÂNTULAS DE GLOXÍNIA (Sinningia speciosa Lood. Hiern.) PROVENIENTES DE CULTURA DE TECIDOS ${ }^{1}$
}

\author{
ADRIANO BORTOLOTTI DA SILVA ${ }^{2}$ \\ MOACIR PASQUAL ${ }^{3}$ \\ ANNA LYGIA DE REZENDE MACIEL ${ }^{2}$ \\ LEONARDO FERREIRA DUTRA ${ }^{4}$
}

\begin{abstract}
RESUMO - A gloxínia é uma planta ornamental cultivada pela exoticidade e variação de coloração de suas flores. Objetivou-se avaliar a influência residual da citocinina 6-Benzilaminopurina (BAP) usada durante a cultura in vitro sobre o processo de aclimatização de gloxínia (Sinningia speciosa Lood. Hiern.). As concentrações de 0,$0 ; 0,5 ; 1$ e 2,0 $\mathrm{mg} \mathrm{L}^{-1}$ de BAP, em cultivo in vitro, foram combinadas com os substratos: vermiculita, plantmax ${ }^{\circledR}$ e vermiculita + plantmax ${ }^{\circledR}$, durante o processo de aclimatização. Após o processo de inoculação in vitro, o material foi transferido para sala de cres-
\end{abstract}

cimento com temperatura de $26 \pm 1^{0} \mathrm{C}$, intensidade luminosa de $35 \mu \mathrm{mol} \mathrm{m} \mathrm{m}^{2} \mathrm{~s}^{-1}$ e fotoperíodo de 16 horas, permanecendo nessas condições por 60 dias. Após esse período, as plantas obtidas foram plantadas nos diferentes substratos. As avaliações foram efetuadas após 120 dias, em casa-de-vegetação, registrando-se o número de brotos, peso da matéria fresca do sistema radicular, peso da matéria seca da planta e número de flores. Os melhores resultados foram obtidos com o cultivo em substrato plantmax ${ }^{\circledR}$ ou plantmax ${ }^{\circledR}+$ vermiculita advinda de meio de cultura in vitro isento de BAP.

TERMOS PARA INDEXAÇÃO: Gloxínia, micropropagação, regulador de crescimento.

\section{BAP AND SUBSTRATES ON GLOXINIA (Sinningia speciosa Lood. Hiern.) PLANTLETS FROM TISSUE CULTURE ACCLIMATIZATION}

\begin{abstract}
The present work aimed to evaluate the influence of concentrations of 6-benzylaminopurine (BAP) used in acclimatization of gloxinia (Sinningia speciosa Lood. Hiern). Concentrations of BAP (0.0; $0.5 ; 1.0$ and $2.0 \mathrm{mg} \mathrm{L}^{-1}$ ) in vitro and substrates (vermiculite, plantmax ${ }^{\circledR}$, and vermiculite+plantmax ${ }^{\circledR}$ ) were tested for acclimatization in every possible combination. After in vitro inoculation, the material was transferred to a growth chamber with temperature of $26 \pm 1^{\circ} \mathrm{C}$ and light intensity of $35 \mu \mathrm{mol} \mathrm{m} \mathrm{m}^{-2} \mathrm{~s}^{-1}$ for 16
\end{abstract}

\begin{abstract}
hours, remaining under these conditions for 60 days. After that period, the plants obtained were transferred to pots containing substrates in a greenhouse. The evaluations were performed 120 days after cultivation. It were measured number of shoots, roots dry weight, above-ground dry weight, and number of flowers. On acclimatization, the best results for the variables were obtained with the use of the substrate Plantmax ${ }^{\circledR}$ or Plantmax $®+$ vermiculite for plants originated from culture tissue.
\end{abstract}

INDEX TERMS: Gloxinia, micropropagation, growth regulator.

\footnotetext{
1. Parte da Dissertação de mestrado do primeiro autor apresentada à UNIVERSIDADE FEDERAL DE LAVRAS/ UFLA, Caixa Postal 37 - 37200-000 - Lavras, MG.

2. Engenheiro Agrônomo, MS em Fitotecnia - Departamento de Agricultura da UFLA.

3. Engenheiro Agrônomo, Dr., Professor Titular, UFLA.

4. Engenheiro Agrônomo, Dr., Bolsista Recém-Doutor/CNPq.
} 


\section{INTRODUÇÃO}

A gloxínia (Sinningia speciosa Lood. Hiern.) é uma planta ornamental da família das Gesneriáceas, comumente encontrada nas matas quentes da Serra do Mar, nos Vales do Paraná, e em São Paulo, nas regiões úmidas de Santos e Ubatuba, atravessando o Rio de Janeiro até o Espírito Santo. É largamente comercializada pela sua exoticidade e variação de coloração das flores. $\mathrm{Na}$ maioria dos locais, a floração ocorre de setembro a maio, onde essas plantas são conhecidas como gloxíniade-cachimbo, pito ou campainha (Winters, 1996). A propagação é feita, geralmente, via sementes, revelando a variabilidade existente (Longhi \& Tombolato, 1995).

A propagação dessa espécie pela cultura de tecidos é uma alternativa para a obtenção de um grande número de plantas, em curto espaço de tempo, garantindo uniformidade genética (Dublin, 1984) e qualidade fitossanitária do material. Esse tipo de propagação vem sendo utilizado, principalmente, para espécies de grande valor ornamental (Queralt et al., 1991).

As citocininas como a 6-benzilaminopurina (BAP) promovem a formação de brotos e alta taxa de multiplicação em muitos sistemas de micropropagação, ao passo que a CIN e o 2iP permitem o crescimento normal sem brotações múltiplas (Hu \& Wang, 1983). As citocininas, de forma geral, promovem produção de partes aéreas, mas seu excesso pode ser tóxico e levar ao encurtamento dos entrenós e a problemas na fase de enraizamento (Lane, 1979; Leshem et al., 1988). Outros efeitos residuais atribuídos a citocininas têm sido observados nas plantas após o transplantio. Menor capacidade de sobrevivência, quebra da dominância apical, deformação de frutos e manutenção de um hábito arbustivo são algumas dessas características (Grattapaglia \& Machado, 1998).

A aclimatização é a fase da micropropagação em que ocorre a transferência das mudas produzidas in vitro para o ambiente externo, a casa-de-vegetação (Deberg \& Maene, 1981) e, posteriormente, para o campo. Um dos obstáculos para a aplicação prática dos métodos de cultura de tecidos é a dificuldade de transferir com sucesso as mudas das condições in vitro para o solo em razão da diferença entre as duas condições (Read \& FelIman, 1985). A aclimatização é constituída de duas etapas: enraizamento (in vitro e in vivo) e transferência para condições não estéreis com temperatura e umidade controladas (Dunstan \& Turner, 1984). Fatores como genótipo, estresse hídrico, alteração do metabolismo heterotrófico (in vitro) para autotrófico, infecção por patógenos e estresse pela luz, além das variações de temperatura, interferem no sucesso da aclimatização.
A escolha do substrato apropriado pode ser decisivo para aclimatização. O substrato deve ser de baixa densidade, rico em nutrientes, composições química equilibrada e física uniforme, boa aeração e drenagem, boa coesão entre as partículas e raízes, e estar, preferencialmente, isento de plantas daninhas e com boa flora bacteriana (Coutinho \& Carvalho, 1983). Segundo Howard (1987), as mudas provenientes do cultivo in vitro têm menos de $5 \mathrm{~cm}$ de altura quando transplantadas, de modo que necessitam aumentar entre 10 a 20 vezes o seu tamanho para serem utilizadas comercialmente.

Com o presente trabalho objetivou-se verificar a influência do BAP no processo de aclimatização de plantas de gloxínia produzidas in vitro.

\section{MATERIAL E MÉTODOS}

O presente trabalho foi dividido em duas etapas. Na primeira, foram selecionados explantes com 10 mm de comprimento e 3 gemas axilares de plântulas mantidas in vitro. $\mathrm{O}$ meio basal utilizado foi o $\mathrm{MS}(\mathrm{Mu}-$ rashige \& Skoog, 1962), contendo 50\% da concentração original dos sais. Os tratamentos constaram da adição de BAP, nas seguintes concentrações: 0,$0 ; 0,5 ; 1$ e 2 mg $\mathrm{L}^{-1}$. O meio foi distribuído em frasco de $200 \mathrm{~cm}^{3}$ na proporção de $40 \mathrm{~mL}$ por frasco. Na segunda etapa, realizada após 60 dias de cultivo in vitro, as plântulas obtidas foram retiradas dos frascos, lavadas com água corrente com o objetivo de retirar o excesso do meio de cultura e transferidas para vasos contendo os substratos: vermiculita, plantmax ${ }^{\circledR}$ e a mistura de 1vermiculita:1 plantmax $®(\mathrm{v} / \mathrm{v})$. O experimento foi conduzido em casa-de-vegetação com sistema de nebulização intermitente garantindo alta umidade relativa, temperatura noturna de $15^{\circ} \mathrm{C}$ e diurna em de $30^{\circ} \mathrm{C}$ e ventilação forçada. Foram realizadas pulverizações quinzenais com $1 / 2 \mathrm{MS}$ acrescido de $1 \mathrm{~g} \mathrm{~L}^{-1}$ de Benomyl.

$\mathrm{O}$ delineamento experimental foi o inteiramente casualizado em esquema fatorial $4 \times 3$, com quatro repetições e cinco plantas por parcela.

Após 120 dias em casa-de-vegetação, foram realizadas as avaliações nas seguintes características: número de brotos, peso da matéria fresca do sistema radicular, peso da matéria seca da planta e número de flores.

\section{RESULTADOS E DISCUSSÃO}

Na Tabela 1 consta a análise de variância para as características avaliadas. Houve significância para o efeito do BAP para número de brotos. Para as demais variáveis, houve interação significativa entre os fatores estudados. 
Durante o processo de aclimatização, houve a produção de maior número de brotos em plantas advindas de meio contendo $1 \mathrm{mg} \mathrm{L}^{-1}$ de BAP, atingindo 1,45 broto por planta, ponto a partir do qual o uso de BAP passou a ser prejudicial à multiplicação (Figura 1). Essa brotação durante a aclimatação pode ser explicada por um possível efeito residual das citocininas. Esse efeito residual pode ser de interesse quando se trata, por exemplo, de um processo de rejuvenescimento in vitro de espécies lenhosas pelas seguidas exposições à citocinina. Porém, pode ser um fator limitante na fase de enraizamento (Grattapaglia \& Machado, 1998).

Para peso da matéria fresca da parte aérea (Figura 2), observa-se que melhores resultados foram obtidos de plantas cultivadas em substrato plantmax + vermiculita, oriundas da dose 0 de BAP, atingindo $89 \mathrm{~g}$ por planta. Por meio desses resultados, demonstram-se os efeitos negativos do BAP no crescimento da parte aérea em plantas aclimatizadas.

TABELA 1 - Análise de variância para número de brotos (NB), peso da matéria fresca da parte aérea (PMFPA), peso da matéria seca total (PMST), peso da matéria fresca do sistema radicular (PMFSR), número de flores (NFLOR) de plântulas de gloxínia. UFLA, Lavras - MG, 2001.

\begin{tabular}{|c|c|c|c|c|c|c|}
\hline \multirow{2}{*}{$\begin{array}{c}\text { Causas de } \\
\text { Variação }\end{array}$} & \multirow{2}{*}{ GL } & \multicolumn{5}{|c|}{ QM } \\
\hline & & NB & PMFPA & PMST & PMFSR $^{1 /}$ & NFLOR $^{1 /}$ \\
\hline BAP & 3 & $0,909 * *$ & $6612,54 * *$ & $30,786^{* *}$ & $2,276^{* *}$ & $6,401 * *$ \\
\hline Substrato & 2 & $0,142 \mathrm{~ns}$ & $4554,14^{* *}$ & $17,545^{* *}$ & $0,679^{* *}$ & $2,955^{* *}$ \\
\hline BAP x Subst. & 6 & $0,298 \mathrm{~ns}$ & $1364,52 * *$ & $6,344^{* *}$ & $0,326^{*}$ & $1,854 * *$ \\
\hline Resíduo & 36 & 0,205 & 305,07 & 1,529 & 0,116 & 0,251 \\
\hline CV (\%) & & 47,14 & 76,76 & 72,60 & 24,71 & 34,98 \\
\hline
\end{tabular}

${ }^{1 /}$ Observações transformadas segundo $(\mathrm{X}+1)^{0,5}$

** significativo a1\% de probabilidade.

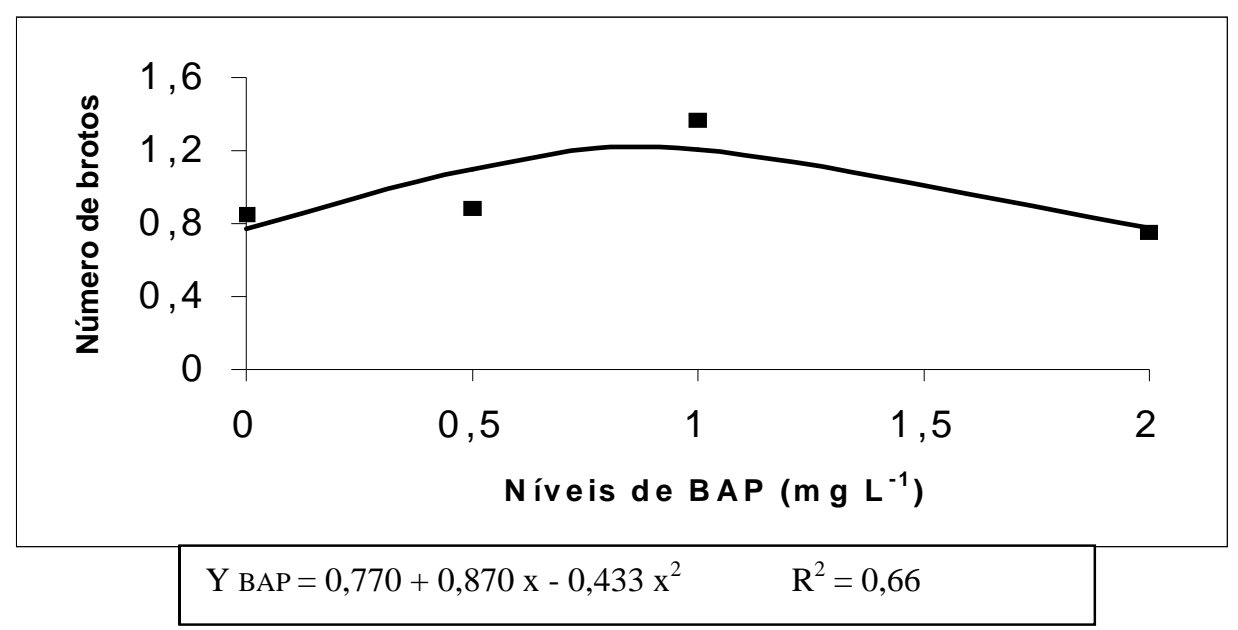

FIGURA 1 - Número de brotos em plantas de gloxínia advindas de cultivo in vitro em diferentes concentrações de BAP em processo de aclimatização. UFLA, Lavras - MG, 2001. 
O substrato comercial plantmax ${ }^{\circledR}+$ vermiculita induziu maior peso da matéria seca da planta (Figura 3), que é a expressão do crescimento real do sistema radicular e da parte aérea, quando foram utilizadas plantas advindas do cultivo in vitro na ausência do regulador de crescimento BAP, comportando-se de forma bastante semelhante a resposta obtida para peso da matéria fresca da parte aérea.

Os melhores resultados para peso da matéria fresca do sistema radicular foram obtidos com o emprego de plantmax ${ }^{\circledR}$ ou plantmax ${ }^{\circledR}+$ vermiculita (Figura 4). Da mesma forma que para peso da matéria seca de plantas,

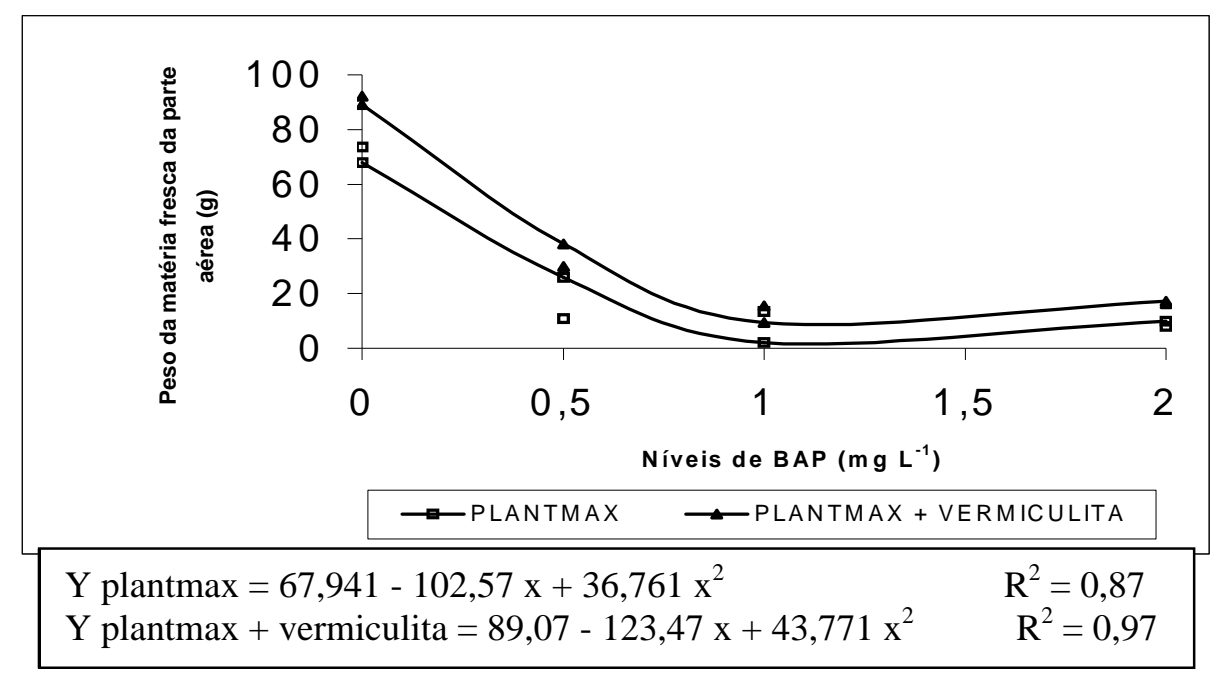

FIGURA 2 - Peso da matéria fresca da parte aérea de plantas de gloxínia advindas de cultivo in vitro em diferentes concentrações de BAP em processo de aclimatização. UFLA, Lavras - MG, 2001.

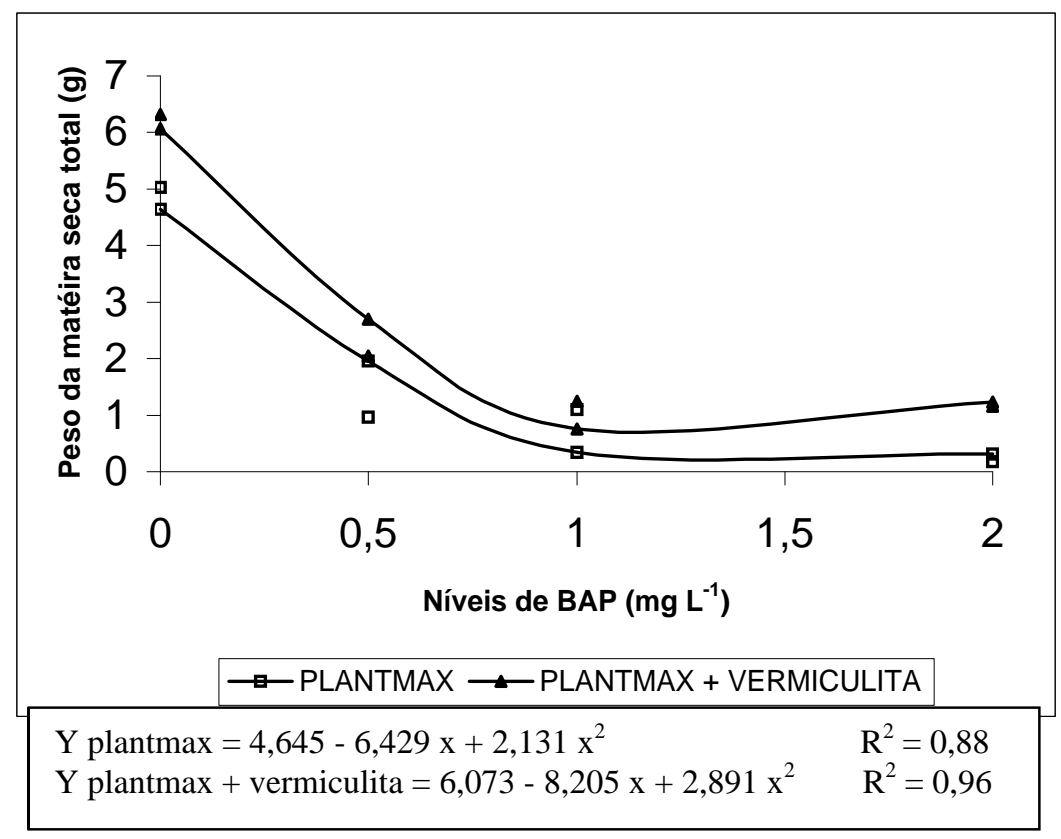

FIGURA 3 - Peso da matéria seca total de plantas de gloxínia advindas de cultivo in vitro em diferentes concentrações de BAP em processo de aclimatização. UFLA, Lavras - MG, 2001.

Ciênc. agrotec., Lavras. V.27, n.2, p.255-260, mar./abr., 2003 
houve um decréscimo de peso quando se aumentou a concentração de BAP. Esses resultados são concordantes com os obtidos por Lane (1979) e Leshem et al. (1988), segundo os quais o uso de citocininas pode trazer problemas para a fase de enraizamento, e também por Grattapaglia \&
Machado (1998), que observaram que após o transplantio houve menor capacidade de sobrevivência em eucalipto. Uma fase intermediária de alongamento e enraizamento para reduzir possíveis efeitos residuais do BAP no processo de aclimatização pode ser uma alternativa interessante.

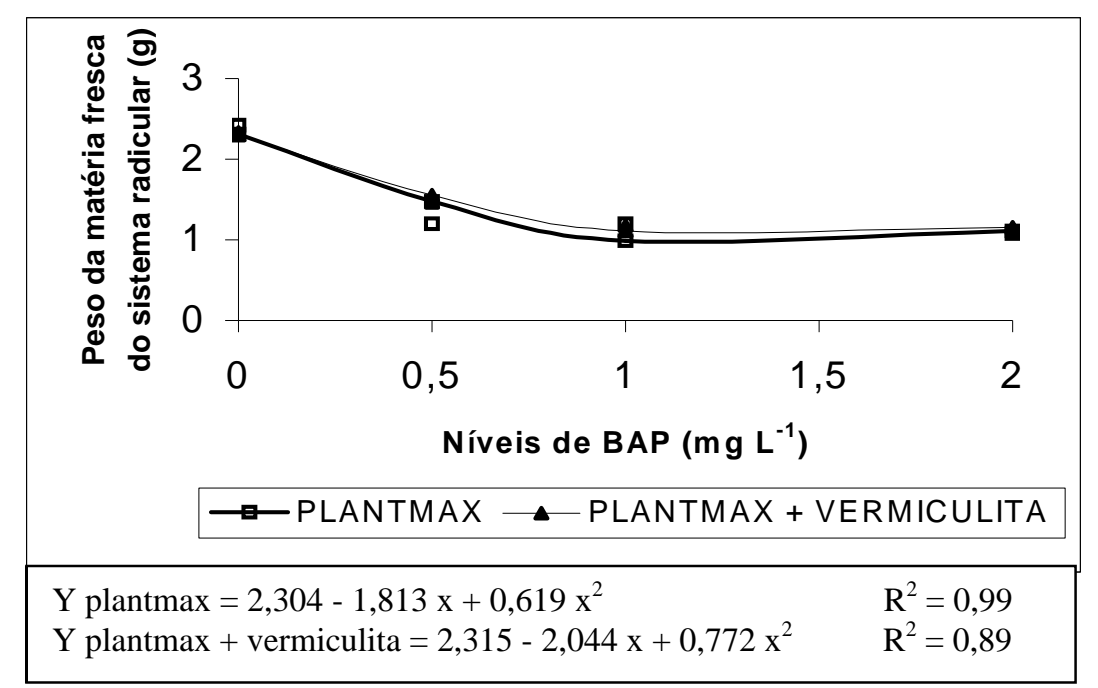

FIGURA 4 - Peso da matéria fresca do sistema radicular de plantas de gloxínia advindas de cultivo in vitro em diferentes concentrações de BAP em processo de aclimatização. UFLA, Lavras - MG, 2001.

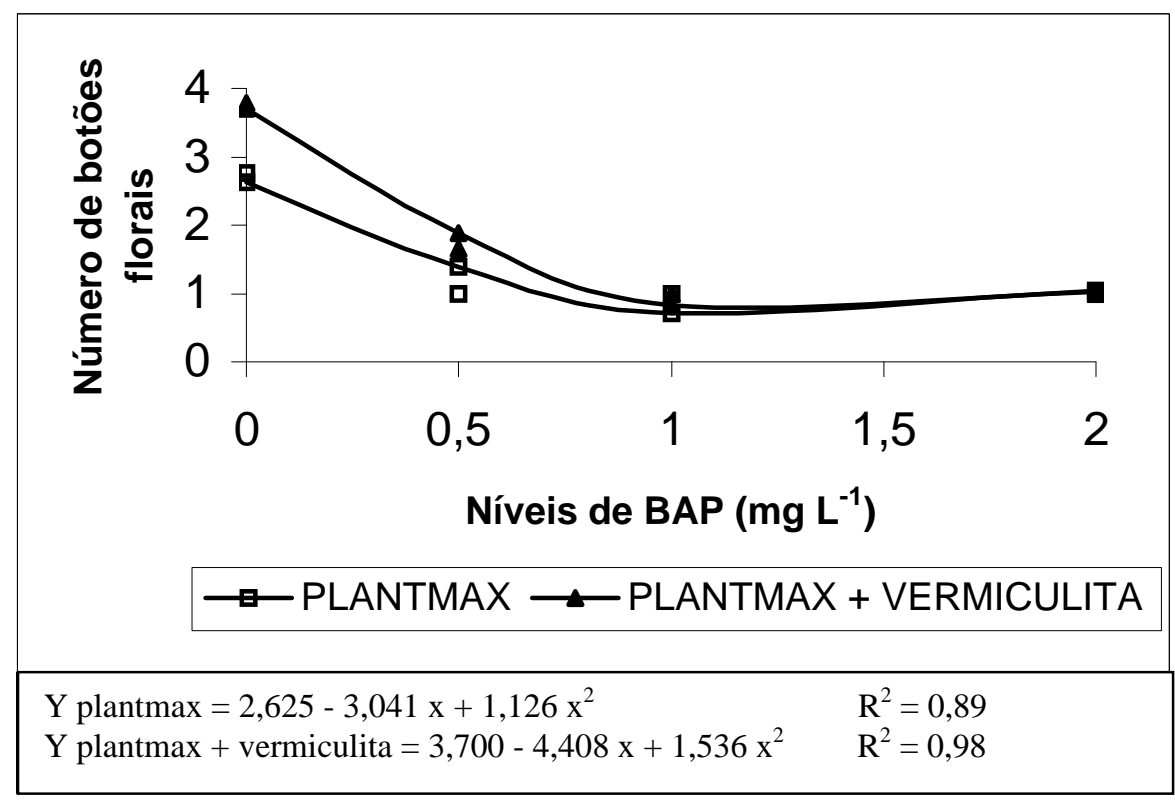

FIGURA 5 - Número de flores em plantas de gloxínia advindas de cultivo in vitro em diferentes concentrações de BAP em processo de aclimatização. UFLA, Lavras - MG, 2001. 
Para a variável número de botões florais (Figura 5), o melhor resultado foi obtido com o uso de Plant$\max \circledast+$ Vermiculita durante a fase de aclimatização, atingindo 3,69 botões florais, em média, por planta na ausência de BAP. O aumento nas concentrações de BAP proporcionou diminuição no número de botões florais.

\section{CONCLUSÕES}

a) Plantas de gloxínias apresentam maior número de brotos durante o processo de aclimatização, quando provenientes de cultivo in vitro com $1 \mathrm{mg} \mathrm{L}^{-1}$ de BAP.

b) Os substratos plantmax $\AA$ ou plantmax ${ }^{\circledR}+$ vermiculita são próprios para a aclimatização de plantas de gloxínia produzidas in vitro. Pode obter-se maior número de botões florais com o emprego de plantmax ${ }^{\circledR}$ + vermiculita.

c) Para a aclimatização em casa-de-vegetação, deve-se dar preferência a plantas advindas de meio de cultura isento de BAP.

\section{REFERÊNCIAS BIBIOGRÁFICAS}

COUTINHO, M.; CARVALHO, E. J. M. Caracterização das propriedades de alguns substratos para a propagação de mudas. Bragantia , Campinas, v. 14, p. 167-176, 1983.

DEBERGH, P. C.; MAENE, L. V. A scheme for commercial propagation of ornamental plants by tissue culture. Scientia Horticulturae, Amsterdam, v. 14, p. 335$345,1981$.

DUBLIN, P. Tequiniques de reproduction vegétative "in vitro" et amelioration genétique chez les cafélers cultivés. Café, Cacao, Thé, Paris, v. 28, n. 4, p. 231-44, oct./dec. 1984.

DUNSTAN, D. I.; TURNER, K. E. The acclimatization of micropropagated plants. In: VASIL, I. K. (Ed.). Cell culture and somatic cell genetics of plants: laboratory procedures and applications. Orlando: Academic, 1984. v. 1, p. $123-129$.
GRATTAPAGLIA, D.; MACHADO, M. A. Micropropagação. In: TORRES, A. L.; CALDAS, L. S.; BUSO, J. S. (Eds.). Cultura de tecidos e transformação genética de plantas. Brasília: EMBRAPA-SPI/CNPH, 1998. v. 1, p. 183-260.

HOWARD, B. H. Propagation. In: ROM, R. C.; CARLSON, R. F. Rootstocks for fruit crops. New York: Wiley InterScienses, 1987. p. 29-77.

HU, C. Y.; WANG, P. J. Meristem, shoot tip, and bud cultures. In: EVANS, D. A.; SHARP, W. R.; AMMIRATO, P. V.; YAMADA, Y. (Eds.). Handbook of Plant Cell Culture. New York: MacMillan, 1983. v. 1, p. 177-227.

LANE, W. D. Regeneration of pear plants from shoot meristem: tips. Plant Science Letters, Amsterdam, v. 16, p. 337-342, 1979.

LESHEM, B.; WERKER, E.; SHALER, D. P. The effect of cytokinins on vitrification in melon and carnation. Annals of Botany, London, v. 62, p. 271-276, 1988.

LONGHI, A. A.; TOMBOLATO, A. F. C. Gloxínia. [S.1.: s.n.], 1995. 5 p. (Comunicado Técnico - CATI, 123).

MURASHIGE, T.; SKOOG, F. A revised medium for rapid growth and bioassays with tobaco tissue cultures. Physiologia Plantarum, Copenhagen, v. 15, p. 473497, 1962.

QUERALT, M. C.; BERUTO, M.; VANDERSCHAEGHE, A.; DEBERGH, P. C. Ornamentals. In: DEBERGH, M. C.; ZIMMERMAN, R. H. (Eds.). Micropropagation: technology and application. Dordrecht: Kluwer Academic, 1991. p. 215-230.

READ, P. E.; FELLMAN, C. D. Accelerating acclimation of in vitro propagated woody ornamentals. Acta Horticulturae, Wageningen, n. 166, p.15-20, 1985.

WINTERS, G. Campainha em vaso. Revista em Natureza, Porto Alegre, v. 7, n. 103, p. 28-30, 1996. 